\title{
Polymers for biology, medicine and sustainability
}

Citation for published version (APA):

Matson, J. B., \& Baker, M. B. (2019). Polymers for biology, medicine and sustainability. Polymer International, 68(7), 1219-1219. https://doi.org/10.1002/pi.5829

Document status and date:

Published: 01/07/2019

DOI:

10.1002/pi.5829

Document Version:

Publisher's PDF, also known as Version of record

Document license:

Taverne

Please check the document version of this publication:

- A submitted manuscript is the version of the article upon submission and before peer-review. There can be important differences between the submitted version and the official published version of record.

People interested in the research are advised to contact the author for the final version of the publication, or visit the DOI to the publisher's website.

- The final author version and the galley proof are versions of the publication after peer review.

- The final published version features the final layout of the paper including the volume, issue and page numbers.

Link to publication

\footnotetext{
General rights rights.

- You may freely distribute the URL identifying the publication in the public portal. please follow below link for the End User Agreement:

www.umlib.nl/taverne-license

Take down policy

If you believe that this document breaches copyright please contact us at:

repository@maastrichtuniversity.nl

providing details and we will investigate your claim.
}

Copyright and moral rights for the publications made accessible in the public portal are retained by the authors and/or other copyright owners and it is a condition of accessing publications that users recognise and abide by the legal requirements associated with these

- Users may download and print one copy of any publication from the public portal for the purpose of private study or research.

- You may not further distribute the material or use it for any profit-making activity or commercial gain

If the publication is distributed under the terms of Article $25 \mathrm{fa}$ of the Dutch Copyright Act, indicated by the "Taverne" license above, 


\section{Polymers for biology, medicine and sustainability}

Inspired by a recent symposium at the 255th National Meeting of the American Chemical Society titled 'International Symposium on Biorelated Polymers: Innovation in Biomedical Polymers' in New Orleans, LA (March 18-22, 2018), this In Focus section is titled Polymers for Biology, Medicine and Sustainability. The symposium included a variety of talks from researchers around the world on applications of polymers in biomedical fields. As organizers of this symposium, we expanded the topic in this In Focus section to include polymers derived from biological sources for promoting sustainable materials. Submitted papers to be included in this section went through the peer review process with Polymer International reviewers, yielding five outstanding contributions to our field.

The first paper, ${ }^{1}$ from Schulz and coworkers, reviews polymers that are used to sequester toxins in the body and contaminants in the environment. Polymers are discussed that can remove toxins in the body, including bacteria and bacterial-derived toxins, heavy and/or radioactive metals, and biomolecules such as cholesterol. They also review recent progress in developing polymers for removing contaminants from the environment, such as in wastewater. These include heavy and/or radioactive metals and organic pollutants such as pesticides, organophosphates, and polycyclic aromatic hydrocarbons. Sequestration of toxins, whether in the body or the environment, is a growing field with goals of addressing some very difficult problems. Polymers will undoubtedly play a major role in this field in the years to come.

The second paper, ${ }^{2}$ from Matson and coworkers, examines blends of two bio-derived polymers: polylactic acid (PLA) and cellulose triacetate (CTA). A compatibilizing graft copolymer was designed to promote adhesion between the two polymers. Made by ring-opening polymerization from a small number of free hydroxyl groups on CTA, these graft polymers led to increased tensile stress at yield when added to PLA-CTA blends. Compatibilization also afforded films with more consistent mechanical properties than uncompatibilized films, highlighting the potential for biopolymer blends as sustainable and degradable materials.

The third paper $^{3}$ is from Joy and coworkers and focuses on antimicrobial peptidomimetic polyurethanes. The authors appended fatty acid side chains onto a cationic polymer backbone in varying amounts with the goal of determining structure-property relationships. They found that these modifications increased the antimicrobial activity of the polymers but at the expense of increased toxicity, as indicated by hemolysis assays. This work emphasizes the complex interplay between cationic/hydrophobic balance in antimicrobial polymers and its relationship to antimicrobial efficacy and toxicity toward mammalian cells.
The fourth paper, ${ }^{4}$ from O'Reilly and coworkers, discusses labeling of enzymes with fluorophores and poly(ethylene glycol) using functionalized bromomaleimides. Two enzymes, $\alpha$-chromotrypsin and human lysozyme, were tagged in the reaction of protein thiols or amines with dibromo- or monobromomaleimides, forming fluorescent/PEGylated conjugates of the enzymes. Stability of the enzymes at room temperature remained the same before and after tagging, as did their catalytic activity, demonstrating the potential of this conjugation reaction in enzyme-tagging.

Finally, the fifth paper, ${ }^{5}$ from Nelson and workers, investigates the direct-write 3D printing of polymer hydrogels. The authors designed and prepared a series of poly(alkyl glycidyl ether)-block-poly(ethylene oxide)-block-poly(alkyl glycidyl ether) ABA triblock copolymers, several of which gelled in water below their lower critical solution temperature. Rheological properties on select formulations were examined, and one polymer was selected as a hydrogel ink for direct-write 3D printing. Cell viability studies in these hydrogels showed low toxicity, exhibiting their potential as new materials for 3D-printed tissue engineering scaffolds.

We thank the authors and reviewers for their contributions to this In Focus section, as well as Associate Journals Editor Laura Mitchell and Editor-in-Chief of Polymer International, Prof. Tim Long. We have enjoyed reading these contributions and learning about the many new polymers in use and in development with applications across biology, medicine, and sustainability.

GUEST EDITORS
John B Matson
Virginia Tech Department of Chemistry and Macromolecules
Innovation Institute, Blacksburg, Virginia, USA
Matthew B Baker
Maastricht University MERLN Institute for Technology-Inspired
Regenerative Medicine, Maastricht, The Netherlands

\section{REFERENCES}

1 Archer WR, Hall BA, Thompson TN, Wadsworth OJ and Schulz MD, Polym Int 68:1220-1237 (2019).

2 Volokhova AS, Waugh JB, Arrington KJ and Matson JB, Polym Int 68:1263-1270 (2019).

3 Peng C, Zhang T, Ortiz-Ortiz DN, Vishwakarma A, Barton HA and Joy A, Polym Int 68:1255-1262 (2019).

4 Husband JT, Hill AC and O'Reilly RK, Polym Int 68:1247-1254 (2019).

5 Fellin CR, Adelmund SM, Karis DG, Shafranek RT, Ono RJ, Martin CG et al., Polym Int 68:1238-1246 (2019). 